\title{
MULTILINGUALISM IN SOUTH AFRICAN COURTS: THE LEGISLATIVE REGULATION OF LANGUAGE IN THE CAPE DURING THE NINETEENTH CENTURY
}

\section{Gardiol van Niekerk*}

\section{Introduction}

In the European Commission's 2011 report on translation and multilingualism, South Africa is presented as an example of a country where "radical multilingualism" prevails. ${ }^{1}$ That is probably not surprising in view of the record eleven official languages in this country with its multicultural society.

Historically, the multicultural character of South Africa ensued when Bantuspeakers migrated from Nigeria and Cameroon, and entered the territory south of the Limpopo (the northern border of South Africa) around 1700 years ago. ${ }^{2}$ The original inhabitants of the country were the San and the Khoi, collectively known as the Khoisan. The first European intrusion into the territory of a more enduring and organised nature than that of missionaries and merchants, occurred when Jan van

1 European Commission, Directorate-General for Translation Studies on Translation and Multilingualism. Lingua Franca: Chimera or Reality (Jan 2011) available at http://cordis.europa. eu/fp7/ict/language-technologies/docs/lingua-franca-en.pdf(accessed 13 May 2015) at 36.

2 R Olivier \& JD Fage A Short History of Africa (New York, 1979) at 30, 34; PD Curtin Precolonial African History (Washington, 1974) at 38-39; cf, also, GJK Campbell-Dunn Comparative Linguistics. Indo-European and Niger-Congo (Christchurch, NZ, 2004) available at http://home. clear.net.nz/pages/gc_dunn/Comparative_Linguistics.pdf_(accessed 18 Aug 2015) at 14-15.

* $\quad$ Professor, Department of Jurisprudence, University of South Africa.

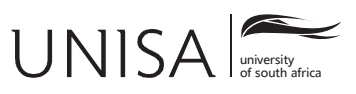


Riebeeck, an official of the Dutch-East India Company, established a refreshment station at the Cape for the Company's ships en route to and from the East Indies. ${ }^{3}$ The refreshment station expanded into a Dutch settlement and introduced deep legal pluralism and with that, multilingualism into the territory. The Dutch language was the first European language imposed on the African population. ${ }^{4} \mathrm{~A}$ few years after Van Riebeeck's arrival, the Dutch East India Company issued an instruction, dated 16 April 1657, that nobody, especially not its officers, were allowed to use any language other than the "mother tongue" (Dutch) in their dealings with slaves and that slaves should be permitted to speak only Dutch. ${ }^{5}$

Although French played a role through the French Huguenots and became fashionable in Cape Dutch High Society in the latter part of the eighteenth century, it never officially gained any foothold.

When the British first occupied the Cape in the late eighteenth century and then again in the early nineteenth century, English was introduced into the language mix. During the short-lived first occupation, there was no concerted effort to advance the English language. The actual imposition of English on the local population started in earnest only during the second British occupation of the Cape.

Academic materials on the history of South African law focus mainly on the introduction of English as a component of a general Anglicisation process and the establishment of British hegemony. But one has to consider whether that was the primary reason for the introduction of English as the legal language. A possibility that should be considered is whether it was introduced in legal proceedings for practical reasons, merely as a lingua franca.

"Lingua franca", literally the language of the Francs,${ }^{6}$ has been variously defined, but in essence it is understood as "a common second language, shared by people

3 Interestingly, in 1620 two English subjects occupied the Cape on behalf of King James I of England. However, he was not interested and the occupation was never confirmed: GG Visagie Regspleging en Reg aan die Kaap van 1652-1806 (Cape Town, 1969) at 40.

4 During the Dutch rule of the Cape, the language of the courts was Dutch. The governor-in-council had extensive powers during the period, including the power to convene the courts and approve all judgments, subject only to the directorate of the Dutch East India Company: GW Eybers Select Constitutional Documents Illustrating South African History, 1795-1910 (New York, 1918) at xix.

5 Instructions by Ryckloff van Goens (Governor-General of the Dutch East India Company 16781681) to Jan van Riebeeck in HCV Leibbrandt Précis of the Archives of the Cape of Good Hope 1649-1662 vol 8 (Cape Town, 1898) Part 2, doc 1, 216-254 at 250. Van Goens pointed out in the instruction that "[t]his will in the course of years cause tranquillity". It is obvious, though, that the lingua franca (Portuguese and Malay-Portuguese) of the early slaves from Angola, Madagascar, Bengal and Guinea was regarded as a threat to the Dutch language: see Peter Broeder, Guus Extra \& Jeanne Maartens Multilingualism in South Africa with a Focus on KwaZulu-Natal and Metropolitan Durban PRAESA Occasional Papers 7 (2 Jul 2012) available at http://www.praesa. org.za/occasional-paper-7-multilingual-in-south-africa-with-a-focus-on-kwazulu-natal-andmetropolitan-durban/ (accessed 28 Jul 2015) at 21.

6 "Francs" in the original, medieval meaning of "lingua franca" referred not to the subjects of the Frankish Empire, but to all the inhabitants of Western Europe other than the Greeks: European Commission (n 1) at 20. 
who are unable to communicate [with one another] in their native tongues". ${ }^{7}$ To this definition is often added that the phenomenon goes hand-in-hand with political dominance and that the introduction of a lingua franca may be a by-product of an empire.

The use of a common vehicular language dates back to a time before the birth of Christ. ${ }^{8}$ Of course, the prominence of Greek and Latin in Western Europe from the Middle Ages is well-known and these two languages shared the position of lingua franca for several centuries. In legal proceedings, the language medium was already regulated during the Roman Principate: the classical jurist Tryphoninus wrote that the praetor should render his decisions in Latin. ${ }^{9}$ But by the time of the Dominate, practicality had steered emperors Honorius and Arcadius to recognise Greek as well. ${ }^{10}$ Thus, Voet commented in his Commentarius ad Pandectas that a judgement should be given "of old in the Latin language only, though afterwards also in the Greek language, as being at the time well-known and in common use". ${ }^{11}$

7 History World $s v$ "lingua franca" available at http://www.historyworld.net/wrldhis/PlainText Histories.asp?historyid=099 (accessed 13 May 2015). In the Encyclopcedia Britannica, sv "lingua franca" available at http://global.britannica.com/EBchecked/topic/342377/lingua-franca (accessed 13 May 2015) it is described as "language used as a means of communication between populations speaking vernaculars that are not mutually intelligible. The term was first used during the Middle Ages to describe a French- and Italian-based jargon, or pidgin, that was developed by Crusaders and traders in the eastern Mediterranean and characterized by the invariant forms of its nouns, verbs, and adjectives. These changes have been interpreted as simplifications of the Romance languages."

8 The term was coined by the Arabs (lîghat al-Ifranj) and documented from the ninth century $\mathrm{AD}$. It was only during the sixteenth century that the term "lingua franca" started appearing in Western European documents: see European Commission (n 1) at 20; Viveka Velupillai Pidgins, Creoles and Mixed Languages: An Introduction (Amsterdam, 2015) at 151. Aramaic was the first example of a vehicular language used as a communication medium between peoples who speak different languages. From the eighth century BC, Babylonian merchants used Aramaic as a second language in the Assyrian and Babylonian empire. It is only in the second century BC that Greek dethroned Aramaic as the lingua franca, even though Aramaic continued to be spoken widely and is today still spoken by some in the Middle East (European Commission (n 1) at 9-10; $c f$, also, Velupillai (n 8) 151-152).

9 D 42148 (2 disp): "Decreta a praetoribus latine interponi debent". Claudius Tryphoninus was a contemporary of Papinian and eighty extracts of his Disputationes were incorporated into the Digest: see Henry John Rory An Introduction to the Study of Justinian's Digest (Cambridge, 2011) at $190-191$.

10 C 745 12: "Iudices tam Latina quam graeca lingua sententias proferre possunt" (AD 397). Honorius was Emperor of the Western Empire AD 393-423 and Arcadius was Emperor of the Eastern Empire AD 383-408.

11421 18: "linguâ olim Latinâ tantum, post etiam Graecâ, tanquam tunc vulgari \& usitata" (vol 2 (Geneve, 1769) tr Percival Gane The Selective Voet being the Commentary on the Pandects by Johannes Voet vol 7 (Durban, 1955). See, also, PC Anders "Judges and judgements" (1911) 28 SALJ 28-35 at 28: "Judgements must be delivered by the judge in an open court, on a business day, and in a language prescribed by the law of the land". It is a known fact that one of the reasons why the Corpus iuris civilis was not popularly received in Justinian's time was that it was written in Latin while the Eastern Empire was dominated by Greek culture and Greek was the lingua franca of the region. However, Latin remained the leading academic and scientific language long after the fall of the Western Empire and it is trite that the legal language of the Western European continent was Latin. 
Indigenous African cultural institutions, including languages, have notoriously been ignored ${ }^{12}$ in the history of early South Africa. Thus the needs of the indigenous population played no role in any decisions relating to judicial language both during the Dutch and the English administrations of the Cape, and later in the territories beyond the borders of the Cape..$^{13}$ This article will focus on the legislative regulation of the language medium in the nineteenth-century Cape courts and on the contest between Dutch and English for the position of the official judicial language.

\section{The introduction of English}

\section{The First British Occupation of the Cape (1795-1803)}

Although the general perception is that English gradually displaced Dutch as official language between 1822 and 1832, and so became the language of the courts, ${ }^{14} \mathrm{a}$ perusal of the Cape government's correspondence with the Colonial Office reveals that efforts to introduce English into the courts started much earlier. The first tentative attempt may in fact be detected two years into the First British Occupation.

When Britain took over in 1795, the seventh article of the Articles of Capitulation secured all privileges of the colonists in accordance with the British principle that a conquered or ceded country retained its laws until a competent authority changed

12 In trade and in missionary activities, interpreters were used to communicate with the indigenous population. There are indications of individual local inhabitants who were able to communicate in Dutch already prior to the arrival of Jan van Riebeeck in 1652. In a letter from Leendert Jansz and N Proot to the Dutch East India Company, dated 26 Jul 1649, regarding the suitability of the Cape as a half-way station, it is, eg, mentioned that some of the local people had learnt to speak short sentences in their interaction with the sailors of the shipwrecked Haarlem, who had been stranded at the Cape for five months: Leibbrandt (n 5) Part 1, doc 1, 3-18 at 14. Further, in a letter from Jan Woutersen to Jan van Riebeeck, dated 12 Oct 1654, he remarked that the Khoi who had accompanied the settlers to Dassen Island were able to understand Dutch, even though they could not yet speak the language: idem doc 51,153-154 at 154. There were also instances of Dutch settlers who had learnt the indigenous languages and acted as interpreters. Nicolaas Gülde, eg, served as interpreter from 1785-1789: HCV Leibbrandt Précis of the Archives of the Cape of Good Hope 1715-1806 F-O vol 2 (Cape Town, 1906) sv "Gülde, Nicolaas" at 504.

13 By the late seventeenth century, the local Khoi were subject to Dutch laws and procedure: $c f$ Eduard Fagan "Roman-Dutch law in its South African historical context" in Reinhard Zimmermann \& Daniel Visser (eds) Southern Cross. Civil Law and Common Law in South Africa (Oxford, 1996) 33-64 at 37-40.

14 See, eg, Wouter de Vos "Roman-Dutch law in South Africa at the end of the century - and thereafter" in Antony Anghie \& Garry Sturgess (eds) Legal Visions of the 21st Century: Essays in Honour of Judge Christopher Weeramantry (The Hague \& London, 1998) 73-98 at 77; James Sturgis "Anglicisation at the Cape of Good Hope in the early nineteenth century" (1982) 11(1) The J of Imperial and Commonwealth History 5-32 at 7ff. 
them. That included their existing laws and freedom of religion. ${ }^{15}$ There was accordingly no change in the character of the courts.

However, soon after, English was for the first and only time during the First Occupation formally introduced into the courts, even if only to a very limited extent. Although Earl Macartney, the Governor during that time, was not in favour of imposing English law and institutions on the Cape, ${ }^{16}$ it was during his tenure that the Proclamation of 24 July $1797^{17}$ abolished appeals from the Court of Justice (Raad van Justisie) at the Cape ${ }^{18}$ to the Court of Justice in Batavia. This Proclamation instituted a Court of Appeals for Civil Cases, consisting of the governor and the lieutenant-governor, and made provision for further appeals to the King-in-Council. As a rule, the governor had a military rather than legal background and was a British official. For obvious reasons, it was determined that appellants and respondents' briefs and statements of their cases to the Court of Appeals had to be translated into English. A proviso was added that the secretary of the court a quo had to certify that the briefs were a true reflection of the proceedings before that court. ${ }^{19}$

The Cape reverted to the Batavian Republic in 1803, only to be recaptured by Britain in 1806. During this Batavian interlude, the status of the courts returned to that before 1795 and Dutch remained the language medium.

\section{The Second British Occupation of the Cape}

\section{The early years}

In 1807, a year after the Cape's second occupation by Britain, ${ }^{20}$ a Court of Appeals for Civil Cases was instituted once again, the instituting proclamation in essence

15 CG Botha "The early influences of the English law upon the Roman-Dutch law in South Africa" (1923) 40 SALJ 396-406 at 396-397; Sturgis (n 14) at 14.

16 Macartney was governor from 1797-1798: Daniel Visser "Cultural forces in the making of mixed legal systems" (2003) 78 Tulane LR 41-78 at 51.

17 Eybers (n 4) doc 64 at 99-101. This Procl confirmed the continued application of the existing laws in as far as they had not been amended or repealed (at 99): "Now considering that the Inhabitants of the Colony have been long accustomed to the subsisting laws and jurisprudence, and that no abuse of the same has come to my knowledge, I think it proper to declare ... that the administration of the civil and criminal Justice do continue on the ancient Ground, except where it shall have already been altered and improved since the surrender of the Colony, or shall hereafter be altered and improved as occasion may require."

18 This was the highest criminal and civil court and was instituted in 1656; cf HJ Erasmus "The interaction of substantive law and procedure" in Zimmermann \& Visser (n 13) 141-161 at 144.

19 Six months earlier, in Jan 1797, a Vice-Admiralty Court had been instituted for the Cape. Being a British court the language medium was English. See HB Fine The Administration of Criminal Justice at the Cape of Good Hope 1795-1828 (unpublished PhD thesis, University of Cape Town, 1991) at 1-2.

20 The Cape was finally ceded to Britain only in 1814. 
repeating the 1797 provisions, including the requirement that briefs had to be in English. ${ }^{21}$ Again, this requirement is not surprising as the governor who served as presiding officer in the Court of Appeals, was invariably of British origin while the character of the Court of Justice remained Dutch. ${ }^{22}$ In 1811 circuit courts were established..$^{23}$ They were founded on the English model and paved the way for the introduction of the English law of procedure. In these courts preference was given to candidates for presiding officers who were conversant in English. ${ }^{24}$

During the second decade of the nineteenth century, the drive for the advancement of English gained momentum. This is generally regarded as part of the Anglicisation endeavour, although the policy of Anglicisation became most prominent only during the 1820s. Anglicisation was not the principal goal of British policy at the Cape. In practice, the colonial policies fundamentally supported the continuation of the existing, predominantly European social order - of course, completely disregarding the indigenous African law and social order. Different colonial secretaries and governors had different views about Anglicisation; in fact, some were quite indifferent towards this ambition. ${ }^{25}$

In 1813, the Governor, Sir John Cradock ${ }^{26}$ publicised his sentiments about the importance of English in an "Advertisement concerning the advantages of acquiring knowledge of the English language". ${ }^{27}$ His reasoning was determined by practical needs: he indicated that commerce had suffered because of the lack of proper translators and because the use of translators was an "imperfect and limited" way of communicating and "contrary to the spirit and effect of government". In consequence, Cradock intended to make a proficiency in English a requirement of government employment "in future generations" when everybody would have had the opportunity of an education in English.

Nevertheless, Anglicisation was also coupled with an objective to "civilise" the Dutch colonists, not unlike the Cape administrators' general goal to "civilise"

21 Procl of 29 May 1807 in Eybers (n 4) doc 65 at 102.

22 In fact, the Dutch civil procedure of Johannes van der Linden was followed in the Court of Justice and remained largely unaltered until 1827: see Erasmus (n 18) at 145.

23 Procl of 16 May 1811 in Eybers (n 4) doc 67 at 103-104; $c f$, also, HJ Erasmus "Circuit courts in the Cape Colony during the nineteenth century: Hazards and achievements" (2013) 19(2) Fundamina 266-299.

24 Fine (n 19) at 4-5.

25 Sturgis (n 14) at 6-7; $c f$, also, Fine (n 19) at 7.

26 Governor of the Cape of Good Hope from 1811-1814.

27 Dated 19 Feb 1813: "His Excellency the Governor conceives it to be necessary to make known his sentiments upon the general acquirement of the English Language, that the earliest attention may be paid to this essential Study by Parents and all Persons concerned in the Education of the Youth of this Colony." See George McCall Theal Records of the Cape Colony 1793-1831: Copied for the Cape Government, from the Manuscript Documents in the Public Record Office, London 36 vols (1898-) (hereafter $R C C$ ) vol 24 at 471-472. 
the indigenous African population. ${ }^{28}$ Certain officials in the employ of the British Administration played an important role in the (British) perception of the Dutch inhabitants of the Cape Colony, especially the so-called "peasantry," as being "rude and uncultivated". ${ }^{29}$ Both Sir John Barrow, Lord Macartney's secretary ${ }^{30}$ during the

28 The drive to "civilise" the indigenous African population is well-documented. Eg, one of the tasks of the Colebrooke-Bigge Commission of Enquiry into the state of the settlement at the Cape of Good Hope was to investigate the condition of the "native tribes" (see the "Copy of the Instructions given to the Commission of Enquiry proceeding to the Cape of Good Hope, Mauritius, and Ceylon": Bathurst [Secretary of State for War and the Colonies 1812 - Apr 1827] to Major WMG Colebrooke and JT Bigge, 18 Jan 1823, in RCC (n 27) vol 15, 237-242 at 240241). There are numerous examples in the Commission's report of this goal to advance the uncivilised indigenous African population in the extracts of evidence and information collected between 1823 and 1827 (Papers Relative to the Condition and Treatment of the Native Inhabitants of Southern Africa, within the Colony of the Cape of Good Hope, or Beyond the Frontier of the Colony. Part I. Hottentots and Bosjesmen; Caffres; Griquas: see Colebrooke to T Spring Rice, 14 Aug 1834 Irish University Press Series of British Parliamentary Papers: Colonies Africa vol 39 (Shannon, 1835) Paper 50). In a report of 1805 on the indigenous population, Genl Jan Willem Jannsens, Governor of the Cape from 1804-1806, remarked that it was "the spirit and absolute wish of the republic and the government of this colony ... to protect the original natives of the colony, namely the Hottentots ... to civilize and render them more happy, and at the same time to cause them to be of the best possible advantage to the country" (idem at 162). There was further an extract from a journal of Col Collins during a tour of the "North Eastern Boundary, the Orange River, and the Storm Mountains" in which he referred to the "Bosjesmen" as an "uncivilized and unfortunate race" (idem at 50). Also enclosed in the Colebrooke-Bigge Commission's report is Lord Charles Somerset's Procl of 23 Jul 1824 which issued regulations regarding fair traffic with the indigenous people. In the preamble of this Procl, reference is made to an earlier Procl of 20 Jul 1821 that instituted an annual fair to be held on the banks of the Keiskamma River "for the purpose of supplying the Caffres with such articles as might tend to civilize them, and to promote industry amongst them ..." (idem at 204).

29 Sir John Barrow An Account of Travels into the Interior of Southern Africa in the Years 1797-1798 ... vol 1 (London, 1801) at 83. In vol 2 (London, 1804) at 79 he describes them as "more indolent, more ignorant and more brutal than any set of men, bearing the reputation of being civilized, upon the face of the earth". His low esteem of the Dutch colonists may be detected throughout both volumes of this work.

30 Barrow arrived at the Cape in 1797, as secretary to the first governor under British rule, Earl Macartney. His work referred to above was "the first detailed English account of the colony of the Cape, after its capture in 1795": see William Wilberforce Bird [1784-1857; Deputy-Governor of Bengal, Acting Governor-General of India] State of the Cape of Good Hope 1822 ... (London, 1823 ) at 1 . Barrow remained interested in and vocal about the Cape even after he left the British colonial service when it was returned to Batavian rule and he had become the Secretary to the Admiralty in London. He voiced his views in the Quarterly Review: see JMRC Cameron sv "Barrow, John" in Oxford Dictionary of National Biography (2004, online ed May 2008) available at $h t t p: / / w w w . o x f o r d d n b . c o m / i n d e x . j s p$ (accessed 20 Aug 2015); cf, also, Sturgis (n 14) at 9. 
First British Occupation, and later Henry Ellis, Deputy-Secretary at the Cape of Good Hope ${ }^{31}$ publicised the fact that they despised the colonists' character and lifestyle. ${ }^{32}$

Barrow's views were expressed in his An Account of Travels into the Interior of Southern Africa in the Years 1797-1798, the first standard work on the Cape of Good Hope that appeared at the turn of the century ${ }^{33}$ and later in various articles he had published in the Quarterly Review, a popular literary and political journal in Britain. He saw reform of the language policy as an important tool in the process of civilisation, the ultimate goal of which would be to make "the next generation ... Englishmen". According to him "the general introduction of our laws and manners" would follow if the English language were established and all official documentation was rendered in English. ${ }^{34}$ But civilising the colonists was not his only goal; he also aspired to attain a harmonious community through a single language ${ }^{35}$ - a notion that would appear again some years later.

Of course, the perception of the Dutch culture being generally inferior encompassed also their law and it is not surprising that Ellis voiced the sentiment to the Colonial Office in London that there should be "some modification of the Colonial Laws ... which are in many points founded upon principles abhorrent to English practice". ${ }^{36}$

By 1821 the idea of a general reformation of the courts had come to the fore in the correspondence with the Colonial Office. Two memoranda emanating from Ellis, as Deputy-Secretary at the Cape, proposed several changes,${ }^{37}$ most of which were eventually implemented by the Charters of Justice, however, not on Ellis's

31 Ellis was the third son of the Earl of Buckinghamshire, and was appointed as Deputy-Secretary at the Cape of Good Hope in 1819: Bathurst to Somerset, 1 Mar 1819, in RCC (n 27) vol 12 at 157. One of Ellis's tasks was to "prepare the way" for the 1820 settlers. It is evident from Ellis's letters to the Colonial Office (to Goulburn, Under-Secretary of State for War and the Colonies 1816-1821 and to Robert Wilmot Horton, Under-Secretary of State for War and the Colonies 1821-1827) that he took his task seriously and that he was an avid supporter of the drive towards Anglicisation and the language policy.

32 While Ellis regarded them as violent and barbaric, he nevertheless appreciated them as "an admirable description of force" against their "savage neighbours" and as "a great means of clearing our frontier" from the threat of the indigenous population: see Ellis to Goulburn, 19 Oct 1819 , in $R C C$ (n 27) vol 12 at 348-350 at 348.

33 Twenty years after its publication, Edward Blount [the name of the author of this book was unknown until 1943 when it was attributed to Blount, a barrister-at-law] Notes on the Cape of Good Hope, Made During an Excursion in that Colony in the Year 1820 (London, 1821) at 151 still recognised Barrow's book as the "standard work upon the Cape", but noted that it was "of somewhat ancient date".

34 Sturgis (n 14) at 9; Visser (n 16) at 52.

35 Ibid.

36 Ellis to Goulburn, 22 Oct 1819, in $R C C$ (n 27) vol 12, 350-351 at 351; cf, also, Sturgis (n 14) at 9-10. This view of the colonists' law is clearly similar to the British Administration's perception of the indigenous African law which gave rise to the notorious repugnancy clause.

37 Ellis to Bathurst, 1 Dec 1821, and two enclosures, in RCC (n 27) vol 14 at 183-187. 
recommendation but on that of the Colebrook and Bigge Commission of Enquiry that was instituted two years later to investigate the state of affairs at the Cape.

An underlying reason for the proposed reforms was to sever the Cape's ties with the Netherlands as the Cape was seen as "an integral part of the Colonial Dominion of Great Britain". ${ }^{38}$ The introduction of English as the exclusive official language was regarded as an important first step in this endeavour, because the continued use of Dutch was perceived as perpetuating the bond with Holland. Ellis viewed the Church and Bar as instrumental in strengthening the ties with the Dutch culture and forms of civil administration as their members were "the only educated classes" 39 in the Colony and had received their education and training in Holland. Most of the Dutch colonists, especially in Cape Town, ${ }^{40}$ were familiar with English due to their extended contact with the language for almost twenty-five years. ${ }^{41}$ By contrast, the English inhabitants could not understand Dutch and had to rely on translators, also in legal proceedings, given that the language medium of the Court of Justice in Cape Town was still Dutch. Also, municipal administration and correspondence had to be translated into English and this caused unnecessary duplication and adversely affected the English inhabitants, particularly the merchant class: trade was conducted almost exclusively in English "and yet the various cases incident to English Shipping and English commerce generally, [were] tried in a foreign language [Dutch] before a Court, the members of which, if not wholly unacquainted with the English language, are certainly quite incompetent to decide on interpretations of contracts, policies of insurances, licenses and other similar matters submitted to their decision". ${ }^{42}$ In civil cases, the Court of Justice conducted business mostly in written pleadings rather than viva voce. Ellis thus proposed that "an examination" in English be introduced as a requirement for holders of civil office.

The fact that the judiciary was largely untrained and unable to speak English, ${ }^{43}$ had elicited mockery of the Court of Justice and, as to be expected, wide-spread

38 Idem (Encl 1) at 183.

39 Ibid.

40 In certain districts, such as Albany and Uitenhage which were principally inhabited by British Settlers, English was the dominant language. These districts further had English magistrates, mainly because the commanding officers of the district usually also filled that office. Ellis further pointed out that the only landdrost who was not conversant in English, in Tulbagh, was "on the eve of retiring from extreme age": idem at 185.

41 This was also confirmed in a letter by William Dunn (an 1820 settler) to the Secretary of War (9 Jun 1821, in $R C C$ (n 27) vol 14 at 20) in which he wrote that "the Dutch Authorities ... having practiced the English Language for about eighteen years could, if they would, inform the colonists of their arrangements in good English" (the emphasis in the original is significant).

42 Ellis to Bathurst, 1 Dec 1821, and two enclosures, in RCC (n 27) vol 14 at 183-187 (Encl 1) at 185.

43 William Dunn, however, was of the opinion that the Dutch officials were competent in English, remarking in a letter to the Colonial Office that while the "Dutch are generally like the untutored peasants of England", the Dutch officials had been "frightened by their conquerors" and "speak a good English". He accordingly predicted that the court officials would not retire merely because the language of the courts was changed: Dunn to the War Secretary of War, 9 Jun 1821, in RCC (n 27) vol 14 at 21. 
discontent. ${ }^{44}$ Ellis therefore recommended a reduction in the number of judges from seven to three: the only judge that he valued worthy to be spared the axe was the Chief Justice, Sir John Truter, even though he had been trained in Holland. ${ }^{45}$ All the other members of the Bench had no legal education and were "imperfectly acquainted with the English language". ${ }^{46}$ The single reason for their election to the Bench had been that their sound financial positions safeguarded them against any accusation that corrupt motives could be behind alleged erroneous decisions. That the Court of Justice was not competent to try English commercial legislation was to be expected and was confirmed by frequent complaints. Ellis's solution was that the Admiralty jurisdiction should vest in the Court of Justice and that the judge of the Vice-Admiralty Court should become a puisne judge. This was a logical proposition, as the Vice-Admiralty Court was a British Court manned by a British judge. ${ }^{47}$ These changes would have paved the way for the adoption of the English language and for a modification of the colonial laws. ${ }^{48}$

But not everyone was in favour of the introduction of English as the exclusive language in the courts. In 1820, Edward Blount, an English barrister-at-law, commented that it was "a fair subject of complaint, that, in an English colony, all proceedings are in the Dutch language; an Englishman being heard through the medium of an interpreter: whereas it would be easy to hear trials in either language, and then the court would be open to no imputation of misconstruction". ${ }^{49}$

44 See, eg, Bishop Burnett [an aggrieved 1820 settler] to Bathurst, 30 Jul 1822, in RCC (n 27) vol 14, 493-497 at 496: "The administration of justice is notoriously a burlesque, and a theme of laughter and ridicule ... The members of the Court of Justice, on whose fiat hang the liberties and properties of the British Subject, are all Dutch, bearing to us English the most unextinguishable hatred ... [they] are for the most part unacquainted with their own laws ... ." See, also, Barrow (n 29) vol 2 at 90-92; he observed (at 90) that certain aspects of their procedure "was particularly repugnant to the feelings of Englishmen and to the principles of English jurisprudence" and he was particularly scathing about the "provincial judicature" (at 338-339). He was no less contemptuous about the attorneys "who, in the Cape, may truly be called a nest of vermin" without any knowledge of the law (at 421).

45 Sir John (Johannes Andreas) Truter studied in Leyden and obtained a doctor of laws in 1787. He must not be confused with Dr PJ Truter, a medical doctor who qualified in the Netherlands and served on the Court of Justice from 1823-1827: see IG Farlam "The origin of the Cape Bar" (1988) Apr (1) Consultus 36-39 at 36.

46 Ellis to Bathurst, 1 Dec 1821, and two enclosures, in RCC (n 27) vol 14 at 183-187 (Encl 2) at 186.

47 In 1821, when Ellis made these proposals, George Kekewich, trained at the Inns of Court, was, and had been for many years the Judge of the Vice-Admiralty Court: Stephen D Girvin "The architects of the mixed legal system" in Zimmermann \& Visser (n 13) 95-139 at 100.

48 Of course, one other puisne judge had to be added. The only problem at that stage though was to find a practicing attorney or advocate willing to take up the position as the salaries of the judges were so low. It turned out that when the Supreme Court of the Colony of the Cape of Good Hope was eventually established in 1827 , there was no problem in finding suitable candidates who met the Royal Charter of Justice's requirements of being members of the English, Scots or Irish Bars.

49 My emphasis. See Blount (n 33) at 77. 
The Colonial Office responded favourably to Deputy-Secretary Ellis's suggestions regarding the introduction of English as exclusive, official language in business and judicial proceedings and accordingly instructed the Governor, Lord Charles Somerset, ${ }^{50}$ to effect by proclamation the necessary changes to the language policy. Somerset was directed to abrogate any law that entrenched the use of Dutch as the official language. As an interim measure both Dutch and English were to be allowed for a certain period until English could be exclusively adopted. ${ }^{51}$

The Colonial Office supported the suggested changes to the Bench as a necessary step towards the introduction of English in the courts. It likewise supported the proposed retention of Chief Justice Truter. ${ }^{52}$ The feeling was that the drastic reduction in the number of judges would not impact negatively on the business of the court but would rather contribute to greater effectiveness, as one properly trained lawyer would be "superior in efficiency to two Members of the present Court thus employed". ${ }^{53}$ Importantly, the Colonial Office firmly believed that a "gradual assimilation of Colonial Law to the more liberal and enlightened maxims of British Jurisprudence" ${ }^{54}$ would follow on the importation of the English language.

Lord Charles Somerset, though, was not enthusiastic about the proposed changes to the Courts, ${ }^{55}$ but, upon the instruction from the Colonial Secretary, he issued the Proclamation of 5 July 1822 for the adoption of English as the exclusive official and judicial language. ${ }^{56}$

\section{2 onwards}

In its preamble, the Proclamation of $1822^{57}$ stated that it was "deemed expedient, with a view to the prosperity of the Settlement, that the Language of the Parent Country should be more universally diffused" and that it would unite the local inhabitants

50 Lord Charles Somerset was the first governor of the Colony of the Cape of Good Hope during the Second British Occupation of the Cape. He was in office from 1814 to 1826. The expansion of the Colony to include the Eastern Cape took place during his term.

51 In commerce the period was set at six months, "as there are few persons so engaged who have not obtained some knowledge of English, and many who actually carry on their communication in that language". In judicial proceedings, though, the period was two years: Bathurst to Somerset, $23 \mathrm{Feb} 1822$, in $R C C$ (n 27) vol 14, 297-298 at 298.

52 See Bathurst to Somerset, 20 May 1822, in RCC (n 27) vol 14 at 371-373. They recommended Sir John Truter as Chief Justice and remarked that the appointment of the existing Judge of the ViceAdmiralty Court as one of the Puisne Judges would immediately bring the necessary expertise, "professional ability and local knowledge" to the new Court.

53 Idem at 373.

54 Ibid.

55 Somerset to Bathurst, 6 Sep 1822, in RCC (n 27) vol 15 at 25-28: Somerset was opposed to the reduction in the number of judges - especially since that would have left the circuit courts with a single judge only. $C f$ Fine (n 19) at 11.

56 See, generally, Fine (n 19) at 8-9.

57 Eybers (n 4) doc 17 at 23-24; RCC (n 27) vol 25 at 215. 
and those of British origin - again the curious notion that a single language would lead to unity. The Proclamation determined, among others, that English would be the exclusive language in all judicial acts and proceedings, in both the superior and lower courts of the Colony. The date set for its coming into operation was 1 January 1827.

Although its implementation date was only 1827, Lord Somerset introduced from 1824 onwards under this Proclamation English as the exclusive language medium in certain minor courts. It appears that the reason behind his further proclamations was the needs of practice. For example, in the Albany district the use of English was indicated because "in almost every case brought before the local Court ... the parties use English, and ... the only two (out of Seven Members who compose that Court) who are not Englishmen born, are well acquainted with the English Language". ${ }^{58}$ Somerset further established Courts for the Cognizance of Minor Civil and Criminal Cases in Simon's Town and instituted English in them as the exclusive language because in that area the majority of the population consisted of "British-born Subjects". ${ }^{59}$ This happened also in the "Township of Algoa Bay (Port Elizabeth)" because the majority of the inhabitants were "native British subjects" and "it would be highly inconvenient to them to use any other but the English language in their Judicial Proceedings before the said Court of Magistracy". ${ }^{60}$

However, the proposed reform of the courts itself was put on hold. Less than a month after the issue of the Proclamation of 5 July 1822, Robert Wilmot Horton, the Under-Secretary of State in the Colonial Office, proposed the institution of a commission of enquiry into, among other matters, the "state of the settlements", including "the state of the laws" and the "practical administration of justice" of the Cape, Mauritius and Ceylon. ${ }^{61}$ The Commission of Enquiry headed by Major WMG Colebrooke and JT Bigge, received its instructions on 18 January $1823 .{ }^{62}$ The judicial part of its enquiry was to "embrace the whole system and administration of civil and criminal justice ... [and] [t]he introduction of the English language in the courts of law, and in all public proceedings".

58 Procl of 2 Feb 1824 , in $R C C$ (n 27) vol 17, 44-45 at 45.

59 Procl of 3 Dec 1824, in RCC (n 27) vol 25 at 215.

60 Ord 1 of 1825, in RCC (n 27) vol 24, 343-344 at 343; cf, also, $R C C$ (n 27) vol 24 at 260 for the minutes of the Council meeting of 28 May 1822 at which the Ordinance was submitted for approval.

61 [Hansard's Parliamentary Debates] Address to the King on a Commission of Enquiry, 25 Jul 1822, in $R C C$ (n 27) vol 14 at 486-487. In his address to Parliament, he mentioned that measures had already been introduced for English to be the exclusive language in legal proceedings.

62 Copy of the Instructions given to the Commission of Enquiry proceeding to the Cape of Good Hope, Mauritius, and Ceylon: Bathurst to Major WMG Colebrooke and JT Bigge, 18 Jan 1823, in $R C C$ (n 27) vol 15 at 237-242. 
The report of the Colebrooke and Bigge Commission was released on 6 September $1826 .{ }^{63}$ One of their recommendations was that English be introduced as the only language in the courts. The first and second Royal Charters of Justice followed on this report. However, it was only in 1828, after the implementation of the First Charter of Justice, that the necessary fundamental changes were effected to the court system.

The institution of the Commission of Enquiry did not stop the steady flow of communication about the deficiencies of the courts - specifically the Bench between the Colonial Government and the Colonial Office. The name of the Chief Justice, Sir John Truter, regularly crops up in the correspondence and it is obvious that he was regarded as an important means to effect the change in the courts from Dutch to English.

Truter was Secretary to the Government during the Batavian rule prior to the Second Occupation, and was one of those who had signed the Articles of Capitulation. ${ }^{64} \mathrm{He}$ was highly esteemed by the Cape governors who had great regard for his opinion in matters of public interest and, as indicated, the Colonial Office too supported him. ${ }^{65}$ Although the Secretary to the Cape Government remarked in a letter to the Colonial Office that Sir John's "Dutchified English [was] not very clear", ${ }^{66}$ his command of the language is apparent in the numerous reports and opinions that he compiled for the Government, ${ }^{67}$ and in his correspondence with the Government and the Colonial Office. ${ }^{68}$ Already during his term as fiscal, in 1810, he quoted from

63 The Commission's Report on the administration of justice with a proposed Charter of Justice was despatched to the Cape on 5 Aug 1827: see Goderich [Secretary of State for War and the Colonies Apr - Sep 1827, 1830-1833] to Bourke, in RCC (n 27) vol 32 at 254-273; for a detailed discussion of the Report, see Fine (n 19) at 14-29.

64 See, generally, Graham Botha "Sir John Andries Truter, Kt, LLD, Chief Justice of the Cape of Good Hope" 1763-1845" (1918) 35 SALJ 135-154; cf, also, Fine (n 19) at 6-7.

65 He was Fiscal for a short time, before in 1812 he became the first and last Chief Justice of the Court of Justice. See Botha (n 64) passim. Truter was knighted in 1820. He became a member of the Council of Advice (the duty of which was to assist the governor in important decisions) in 1825 (idem at 150). His role as advisor is apparent in numerous communications from the Cape Government with the Colonial Office. See, eg, Letter from the Chief Secretary to Government [1824-1827] Richard Plasket to Sir John Truter, 7 Jul 1825, in RCC (n 27) vol 22, 181-184 at 182: "His Excellency ... feels himself bound to impress in the strongest manner the necessity of the general introduction of the English language as the only language to be made use of in future in all public and legal transactions of every kind, he feels the force of the observations made by you in regard to such obligation not being binding with reference to Religious Worship, and His Excellency will feel inclined to give the most liberal interpretation to this important point, and he therefore cannot object to the Religious Instruction being for some time to come given in the Dutch Language, provided always that the English language be taught in all the schools."

66 Secretary to Government to Wilmot Horton, 26 Sep 1825, in $R C C$ (n 27) vol 23 at 161.

67 See, eg, his reports on land tenure (drafted for Sir John Cradock in $R C C$ (n 27) vol 8 at 277ff) and taxation (in $R C C$ (n 27) vol 9 at 368ff); $c f$, further, Botha (n 15) at 144-147.

See, eg, the correspondence as fiscal in RCC (n 27) vol 8 passim. 
Blackstone's Commentaries and Bacon in prosecuting a case against the Reverend Laurence Hynes Halloran, Chaplain to the Military and Naval Forces. ${ }^{69}$

Somerset's reluctance to accept the Chief Justice's request to resign for reasons of health ${ }^{70}$ confirms his reliance on Truter in the replacement of Dutch with English in the courts and the envisaged introduction of new judges. ${ }^{71}$ In 1825 , he implored Truter to reconsider his request: "[I]t would certainly obviate many very embarrassing difficulties, if you could be induced to wave the consideration of your Health .... ."72 Truter duly acceded ${ }^{73}$ and remained in office until 1827.

Richard Bourke, Acting Governor from 1826 to 1828, delayed the implementation of the English language in the courts until the new court could be established. ${ }^{74}$ He thought that the exclusive use of English would lead to bizarre consequences if implemented before English judges were in place. For example, where the parties, counsel and the presiding officer were Dutch, documents and pleadings would have had to be translated back and forth into Dutch and English. As a result, he issued an Ordinance in $1826^{75}$ repealing Somerset's Proclamation of 1822 in as far as it determined that English should be the exclusive language in all the courts in the Colony. It determined that Dutch could lawfully be used. In the preamble it was stated that the reason for delaying the introduction of English was that there had been delays due to "unavoidable causes" and that it was deemed "expedient to postpone [the date of introduction] ... until such Arrangements shall be made as may facilitate the introduction of this beneficial measure, and render its utility at once certain and permanent ...". According to section 2, the governor could nevertheless by proclamation determine that English be used "in the Judicial Acts and Proceedings of all or any of the Courts of Justice in this Colony, at such subsequent period as to him shall seem fit." This Ordinance apparently did not affect the proclamations introducing English in the courts of the Albany District, Simon's Town and Algoa Bay.

A year later, Bourke issued Ordinance 33 of 19 Dec $1827,{ }^{76}$ for the creation of the office of Resident Magistrates in anticipation of the Royal Charter of Justice of 1827. Section 7 of this Ordinance declared that all sentences, decrees, judgments, writs and summonses had to be in English.

69 Botha (n 15) at 141-143.

70 Sir John Truter to Lord Charles Somerset, 5 Sep 1825, in RCC (n 27) vol 23 at 45-47.

71 Plasket, though, did not share Somerset's sentiments and was quick to write to the Colonial Office "I hope and trust that you will take advantage of this resignation and send us a Chief Justice without delay ... who may sit in the Court of Appeals until the new Charter with the English language be promulgated and enforced": Secretary to Government to R Wilmot Horton, 28 Sep 1825 , in $R C C$ (n 27) vol 23, 177-180 at 179.

72 Somerset to Truter, 8 Sep 1825 , in $R C C$ (n 27) vol 23, 50-51 at 50.

73 This was transmitted to the Colonial Office on 16 Oct 1825: see $R C C$ (n 27) vol 23 at 303-304.

74 Sturgis (n 14) at 24.

75 Ord 27 of 13 Dec 1826 in Eybers (n 4) doc 71 at 107.

76 Eybers (n 4) doc 73 at 109-112. 


\section{The Royal Charters of Justice}

Although the Colonial Office in the main agreed with the report of the ColebrookeBigge Commission, it did not implement all the suggested changes. Importantly, it found that there was no immediate reason to abolish the existing Roman-Dutch law in favour of English law as recommended by the Commission, but that the newlyappointed judges should gradually assimilate the English law into the Roman-Dutch law. ${ }^{77}$

The First Charter of Justice, dated 24 August 1827, came into force on 1 January 1828. It determined that the language medium of the Supreme Court and circuit courts was to be English. ${ }^{78}$ The new Supreme Court of the Colony's first session was in January 1828: Sir John Wylde was appointed Chief Justice, the senior Puisne Judge was William Menzies, the second Puisne Judge was William Burton and George Kekewich was the third Puisne Judge - naturally they were all British. ${ }^{79}$

The Second Royal Charter of Justice of 4 May $1832^{80}$ came into effect on 1 March 1834. It was in essence identical to the 1827 Charter. Section 32 determined that all sentences, decrees, judgements and orders had to be pronounced by the judges in an open court and in English. Section 39 determined the same for the circuit courts.

It is significant that section 34 which instituted a jury in criminal cases, determined that "[n]o person otherwise competent to serve on a jury [would] be disqualified by reason of his ignorance of the English Language". The same applied to juries in circuit courts. That it would lead to absurd consequences where a person who did not understand English acted as a juror in a case conducted entirely in English, is to be expected. ${ }^{81}$ Not surprisingly, provision was made for interpreters. ${ }^{82}$

77 See Viscount Goderich to Major-General Bourke, 5 Aug 1827, in RCC (n 27) vol 32 at 256: "Without affecting to institute any comparison between the Civil Code of England, and that which formerly prevailed in the Seven United Provinces, it is obvious that the Roman Dutch Law adequately provides for the ordinary exigencies of life in every form of Society, and is not liable to any such inseparable objections as should require its abrupt and immediate abandonment." And at 258: "I am fully prepared to admit the propriety and importance of gradually assimilating the Law of the Colony to the Law of England. The Judges of the Supreme Court will be more competent than any other of the local Authorities to consider by what steps this change could be most conveniently introduced."

78 See $R C C$ (n 27) vol 32, 274-292 at 282.

79 Wylde was the Judge of the Vice-Admiralty Court of New-South Wales and Kekewich was his equivalent in the Cape Vice-Admiralty Court. Menzies was a former member of the Scots Bar and Burton was Recorder of Daventry: see Farlam (n 45) at 37; Girvin (n 47) at 97-100; Fine (n 19) at 48.

80 Issued at the Cape by Procl of 13 Feb 1834.

81 Section 34 was the result of a dispute that arose among the Cape judges whether persons who were not conversant in English should be disallowed to act as jurors. The Secretary of the Colonies eventually stepped in with s 34 . See Erasmus (n 23) at $287 \mathrm{ff}$.

82 Eg, HR van Ryneveld, who held an LLD, acted as such: JS de Lima (comp) Cape of Good Hope Almanac, for the Leap Year, 1840 (Cape Town, 1840) at 84. 
In 1852, the Cape of Good Hope Constitution Ordinance ${ }^{83}$ further strengthened the position of English, when it provided that English should be the language medium in "[a]1l debates and discussions in the Legislative Council and House of Assembly".

The last legislative regulation for the compulsory use of English in the Cape courts was the Act for Amending and Consolidating the Laws relative to the Courts of Resident Magistrates, Act 20 of $1856 .{ }^{84}$

\section{The return of Dutch to the Cape ${ }^{85}$}

English remained the exclusive language in the Cape Parliament and courts for close on a further three decades until two legislative measures were passed to institute equal language rights for Dutch and English in both houses of Parliament and in the courts. ${ }^{86}$

83 Dated 3 Apr 1852 (as amended and confirmed by the Order-in-Council, dated 11 Mar 1853) and declared in s 89 to come into operation on 1 Jul 1853 (Eybers (n 4) doc 29, 45-55 at 55).

84 Section 7: Eybers (n 4) doc 80 at 125-127.

85 When the Zuid-Afrikaansche Republiek (ZAR) was annexed to the British Empire in 1877, the Annexation Procl dated 12 Apr 1877 (Eybers (n 4) doc 198, 448-453 at 452-453) instituted English as the second official language, retaining the status of Dutch. Significantly, in terms of this Procl all laws, proclamations and government notices had to be published in Dutch. In the Legislative Assembly either language could be used. Both languages were allowed in the courts, according to the choice of the parties. According to JM Huisamen "Afrikaans en die Eerste Vryheidsoorlog" (2014) 11 Scientia Militaria South African J of Military Studies 40-44 at 40, the protection of Dutch was a diplomatic move by Theophilus Shepstone who lacked a proper military armed force when he occupied the ZAR in 1877. The ZAR gained independence after the First Anglo-Boer War. Law 1 of 1882 (s 7) (Eybers (n 4) doc 207 n 1 at 477) instituted Dutch as the exclusive language medium in all schools. In terms of s 1 of Law 10 of 1888 (Eybers (n 4) doc 215 at 482-483) Dutch was declared the exclusive official language. Section 3 determined that all officials in the Courts had to use Dutch and that all pleadings had to be in Dutch. However, it could be accompanied by a translation. In the Vereeniging Peace Treaty of 31 May 1902 (Eybers (n 4) doc 173, 345-347 at 346), concluded after the Second Anglo-Boer War, it was agreed in art 5 that Dutch would be taught in the public schools in the Transvaal and the Orange River Colony where the parents desired it and that Dutch would be allowed in the courts of law if that served the administration of justice better.

In the Orange Free State, Dutch was firmly established shortly after it became independent from Britain. Ord 3 of 1854 (Eybers (n 4) doc 160 at 296-270) determined that Dutch would be the exclusive language in the territory and the chief language in all courts of justice as the majority of the population was of Dutch descent and generally not familiar with other languages. It further ruled that any official documentation in another language had to be translated into Dutch and that "[1] anddrosts and other public Offices shall have a sufficient knowledge of both the Dutch and the English language to be able to act as interpreters in all cases".

86 According to Eybers (n 4) at xli, this legislation evidences the increasing influence of the so-called "country people". CP Lucas A Historical Geography of the British Colonies. Volume IV South and East Africa Part I Historical (Oxford, 1900) at 76-77 explains that there was a clear division between the "town" population (those centered around Table Bay whose interests were focused on the passing trade) and the "country" population (the rural dwellers). It is apparent that English gained more ground in the urban setting while Dutch was firmly entrenched in the country. 
In 1882 the Constitution Ordinance Amendment Act ${ }^{87}$ was promulgated. Section 1 repealed section 89 of the Constitution Ordinance of 1852 because it was held to be "repugnant to or inconsistent with the provisions of this Act". ${ }^{88}$ Section 2 restored Dutch as language in the Legislative Council and House of Assembly, awarding it the same status as English. ${ }^{89}$

Some two years later, in 1884, the Dutch Language Judicial Use Act ${ }^{90}$ was passed. Its preamble stated that notwithstanding the provisions of the Charter of Justice and the Courts of Resident Magistrates Act of 1856, it was "expedient to afford facilities for the use of the Dutch language equally with the English in courts of justice and in legal proceedings ... when requested to do so by any of the parties". Interestingly, in terms of section 1, judges of the Supreme Court had a discretion to

87 Act 1 of 1882 in Eybers (n 4) doc 38 at 66.

88 In Natal, the demands of the population had no effect on the introduction of English as exclusive language in the courts. Natal was annexed to the Cape in 1844 and became a separate colony in 1845. In anticipation of their submission to British rule, the Volksraad of Natal made a submission on 4 Sep 1843 to Her Majesty's Commissioner Henry Cloete demanding certain civil liberties. They indicated that they were prepared to submit to the Queen's sovereignty and asked that certain constitutional liberties be guaranteed. Among these were that "the Dutch Language shall be used in all Courts of Law, except where the majority of the inhabitants of the District shall speak English" (Eybers (n 4) doc 107, 174-180 at 175). These demands were ignored and s 22 of Ord 14 of 1845, which established a District Court for Natal, proclaimed English as the sole language in these courts. In terms of s 23 , no juror in criminal cases before a recorder and a jury could be disqualified merely because he could not speak or understand English. Ord 16 of 1846 (Eybers (n 4) doc 140 at 233-235) which created the office of Resident Magistrate determined in s 20: "All sentences, documents, etc." must be in English. This was later reaffirmed in Law 82 of 1889 (Eybers (n 4)doc 150 at 255-259). Law 10 of 1857 (Eybers (n 4) doc 144 at 242246) instituted a Supreme Court of Justice and circuit courts and at the same time English as the exclusive language medium.

89 According to this provision "all debates and discussions in the Legislative Council and House of Assembly [could] be conducted in either English or Dutch, but in no other language".

90 Act 21 of 1884 in Eybers (n 4) doc 86 at 133-134. Interestingly, the survival of the Dutch language in South Africa found support also from the Netherlands. In Oct 1885, the Nederlands ZuidAfrikaanse Vereniging established a study fund for South African students (Studiefonds voor Zuid-Afrikaanse studenten). This fund was later awarded official status and became known as the Stichting Studiefonds voor Zuid-Afrikaanse studenten (The Foundation Study Fund for South African Students). The aim of the fund was not only of an academic nature, but also to strengthen the Dutch cultural influence in South Africa - especially in the two Boer republics, the ZAR and the Orange Free State. Language was regarded as an important vehicle in this endeavour. Then, in 1890, with a view to boosting the position of the Dutch language, Het Fonds ten behoeve van Hollands Onderwijs in Zuid-Afrika was established. I thank my colleague, Dr Heleen Gall, chairperson of The Study Fund Foundation for South African Students for this information. (See, further, the websites of the Foundation Study Fund at http://www.studyfoundation-sa-students. com/en/node/2 and of Zuid-Afrikahuis available at www.zuidafrikahuis.nl/ (both accessed 13 Oct 2015). It is well-known that numerous Southern African lawyers completed post-graduate studies in the Netherlands in the nineteenth century. 
allow the use of both languages whereas resident magistrates, special justices of the peace and field-cornets were required to do so. ${ }^{91}$

Section 2 of this Act caused some problems. In terms of it, a divisional council, by majority decision, or one-third of the registered voters in any division, could request the governor in writing by petition to order that all summonses, notices, and documents referred to in any summons, should be issued in both languages in all courts in the division. ${ }^{92}$ The logical consequence of the provision was that even where all the parties were conversant in one language, or where a party had waived the right to use one language, the documents still had to be translated. That caused unnecessary delays and an escalation in the cost of litigation. The impracticality of this provision was further illustrated by a case in the Aliwal North District where the measure had been proclaimed. In a case before the Circuit Court the defence relied on this provision, arguing that an indictment had to be quashed because it had not been translated in accordance with section 2 of the Act and had to be regarded as pro non scripto. ${ }^{93}$

Indeed, in 1886 the Appeal Court and Sheriff's Duties Act ${ }^{94}$ added a proviso to section 2 of the Dutch Language Judicial Use Act of 1884. According to this section it would not be necessary to issue the process also in Dutch if it was apparent to the officer of the court issuing a summons, notice or document that the person upon whom it was served was "sufficiently acquainted with the English language to understand the purport of such process" or if his command of the Dutch language was insufficient.

That this would cause discontent among Dutch speakers is obvious, and in 1888 the Dutch Language Judicial Use Amendment Act ${ }^{95}$ was promulgated, enacting the same where a person sufficiently understood Dutch or did not understand English.

\section{Conclusion}

It seems that the importation of English in the nineteenth-century Cape courts was not driven only by considerations of dominance or perceptions of cultural superiority, although these were evident in the correspondence of the time. Another important if underlying reason was quite simply the needs of practice and, of course, the need to promote justice for the English-speaking section of the population. The influx of British settlers and administrators, the introduction of Scottish Ministers in the

91 Section 1 reads: "[T]he judges of the superior courts of justice may, and the resident magistrates, special justices of the peace, and field-cornets shall, allow the use of the Dutch language equally with the English language ..." (my emphasis).

92 See Anon "A confusion of tongues" (1885) 2 Cape LJ 151-153 at 153 who described the measure as "a piece of hap-hazard legislation, ill-defined and obscure".

93 See idem 151-153.

94 Act 17 of 1886, s 14 in Eybers (n 4) doc 88 at 135-136.

95 Act 15 of 1888 in Eybers (n 4) doc 89 at 136-137. 
Dutch Reformed Church and of British teachers, added up to a large section of the (European) population - the indigenous African population being considered of no consequence - that could neither speak nor understand Dutch. By contrast, the Dutch colonists who had been exposed to English for a long time could find their way around in English. Further, there was then, as today, much criticism against the use of translators who invariably lacked the necessary legal knowledge, especially in judicial proceedings where the accuracy of the translation is of the essence. Judges were generally not legally educated and the existing legal practitioners who were well-educated and conversant in both English and Dutch were not susceptible to the idea of serving on the Bench because the salaries were too low. It was only practical to import English as the language of the courts.

It took several decades for the British authorities to realise the fallacy of excluding Dutch from legal proceedings and commerce. Eybers saw the legislation that brought Dutch back to the legal forum as evidencing the increasing influence of the so-called "country people" ${ }^{96}$ The Dutch colonists resisted yielding to British supremacy, ${ }^{97}$ a phenomenon that was mirrored also in their resistance to give way to English law and in the consequent survival of Roman-Dutch law in spite of the drive to gradually assimilate it "to the more liberal and enlightened maxims of British Jurisprudence". ${ }^{98}$

In 1909, section 137 of the South Africa Act ${ }^{99}$ declared English and Dutch as the official languages of the Union of South Africa, to be "treated on a footing of equality". In 1925, the Official Languages of the Union Act ${ }^{100}$ amended the Union Constitution and determined that Dutch included Afrikaans retrospectively. Afrikaans eventually replaced Dutch. In both the 1961 and 1983 republican constitutions, English and Afrikaans were entrenched as the official languages. It was only in the new constitutional democracy that indigenous African languages were for the first time recognised and that all of eleven languages were declared official. ${ }^{101}$

Today the language medium in the High Courts is limited in practice to English and Afrikaans, but it is apparent that English has evolved as the legal lingua franca and de facto most proceedings take place in English. In a parliamentary address, the Minister of Justice and Correctional Services recently confirmed his Department's policy "to promote the use of indigenous languages in all our service points". He referred to a legislative framework being in the pipeline to promote the use of African languages in court proceedings as a matter of practical need. ${ }^{102}$

$96 C f \mathrm{n} 86$ above.

97 See Vivian Bickford-Smith "Revisiting Anglicization in the nineteenth-century Cape Colony" (2003) 31(2) The J of Imperial and Commonwealth History 82-95 at 83.

$98 \quad C f \mathrm{n} 45$.

999 Edw 7 c 9 in Eybers (n 4) doc 235, 517-558 at 552; cf, also, De Vos (n 14) at 78.

100 Section 1, Act 8 of 1925.

101 Section 6, Constitution of the Republic of South Africa, 1996.

102 See "Address by Michael Masutha, MP (Adv), Minister of Justice and Correctional Services on the occasion of Justice Budget Vote Debate, Tuesday 19 May 2015, National Assembly, Parliament" 
There is a movement towards the use of African languages as the language medium (the language of record and the court process) in magistrate's courts in KwaZulu-Natal, the Western Cape and Limpopo. This movement is clearly not politically driven. Thus the Mitchell's Plain Magistrate's Court in the Western Cape conducts trials in Afrikaans (notoriously regarded as the apartheid language) and the Khayelitsha Magistrate's Court uses isiXhosa. The endeavour appears to have emerged out of the practical need to expedite justice by getting rid of timeconsuming and invariably inaccurate verbal translations. In the courts where these measures were introduced, the majority of the people and the magistrate speak the same language. The policy of the Department of Justice is that in cases where one of the parties does not speak the language, the case should be conducted in English - the legal lingua franca - and should a case go on review, the records have to be translated in English. ${ }^{103}$

Although language is an integral part of a culture and as such endowed with the subtext of identity, ethnic belonging, shared values, traditions and history, on a practical level it is merely a tool of communication. In a court of law, language should serve the ends of justice. The experience in the magistrate's courts mentioned above testifies to the fact that language can be removed from its personal context and that on an ad hoc basis any of the eleven languages can successfully become the language of record as and when the need arises.

\section{Abstract}

Legal pluralism, and with it multilingualism, was introduced into Southern Africa when the first Dutch refreshment station expanded into a settlement. Dutch remained the official language until after the second British Occupation of the Cape in 1806. Indigenous African cultural institutions, including languages, were notoriously ignored in early South African history and the needs of the indigenous population played no role in any decisions relating to judicial language both during the Dutch and the English administrations of the Cape, and later in the territories beyond its borders. This article focuses on the legislative regulation of the language medium in nineteenth-century Cape courts and the contest between Dutch and English for the position of official judicial language. Today the language medium in the High Courts is limited to English and Afrikaans, but it is apparent that English has evolved as the legal lingua franca and de facto most proceedings take place in English.

available at http://www.justice.gov.za/m_speeches/2015/20150519_BudgetVote.html\# sthash. tk6cRv5I.dpuf (accessed 24 Jul 2015).

103 See Media Club South Africa "African languages in the SA courts" available at http://www. mediaclubsouthafrica.com/land-and-people/1018-indigenous-languages-in-sa-courts (accessed 24 Jul 2015). 